\title{
Telomere dysfunction suppresses multiple endocrine neoplasia in mice
}

\author{
Ji-Hyeon Lee ${ }^{1}$, Miriam Anver ${ }^{2}$, Maria Kost-Alimova ${ }^{3,4}$, Alexei Protopopov ${ }^{3,4}$, Ronald \\ A. DePinho ${ }^{3,5}$ and Sushil G. Rane ${ }^{1}$ \\ ${ }^{1}$ Diabetes, Endocrinology \& Obesity Branch, National Institute of Diabetes \& Digestive \& Kidney Diseases, Bethesda, MD \\ ${ }^{2}$ Leidos Biomedical Research, Inc., Frederick National Laboratory for Cancer Research, Frederick, MD \\ ${ }^{3}$ Dana-Farber Cancer Institute, Boston, MA \\ ${ }^{4}$ Department of Genomic Medicine, University of Texas MD Anderson Cancer Center, Houston, TX \\ ${ }^{5}$ Department of Cell Biology, University of Texas MD Anderson Cancer Center, Houston, TX
}

Correspondence to: Sushil G. Rane, email: ranes@mail.nih.gov

Keywords: Telomerase, Pituitary, Pancreas, Islets, Endocrine Neoplasia

Received: July 31,2014 Accepted: September 5, $2014 \quad$ Published: September 5, 2014

This is an open-access article distributed under the terms of the Creative Commons Attribution License, which permits unrestricted use, distribution, and reproduction in any medium, provided the original author and source are credited.

\section{ABSTRACT}

Multiple endocrine neoplasia (MEN) syndrome is typified by the occurrence of tumors in two or more hormonal tissues. Whereas the genetics of MEN syndrome is relatively well understood, the tumorigenic mechanisms for these cancers remain relatively obscure. The Cdk4 ${ }^{\mathrm{R} 24 \mathrm{C}}$ mouse model develops highly penetrant pituitary tumors and endocrine pancreas adenomas, and, as such, this model is appropriate to gain insight into mechanisms underlying MEN. Using this model, here we provide evidence supporting an important role for telomerase in the pathogenesis of MEN. We observed increased aneuploidy in $C d k 4^{R / R}$ fibroblasts along with significantly elevated telomerase activity and telomere length in $\mathrm{Cdk4}^{\mathrm{R} / \mathrm{R}}$ islets and embryonic fibroblasts. To better understand the role of telomerase, we generated $C d k 4^{\mathrm{R} 24 \mathrm{C}}$ mice with inactivation of the mTERC locus, which codes for the essential RNA component of the enzyme telomerase ( $m$ TERC ${ }^{-/-} C d k 4^{R / R}$ mice). Embryonic fibroblasts and islets derived from mTERC $C^{-/} C_{k d} 4^{R / R}$ mice exhibit reduced telomere length and proliferative capacity. Further, TTERC $^{-1} \mathrm{Cdk}^{\mathrm{R} / \mathrm{R}}$ fibroblasts display reduced transformation potential. Importantly, mTERC ${ }^{-1-} C_{d k 4^{R / R}}$ mice display significantly reduced spontaneous tumorigenesis. Strikingly, we observed dramatic suppression of pituitary tumors and endocrine pancreas adenomas in $m T E R C^{-1-} C d k 4^{R / R}$ mice. Telomere dysfunction suppressed tumor initiation and increased latency of tumor development while not affecting the progression of established tumors. In summary, these results are suggestive of an important role for telomerase in tumor development in the Cdk4 ${ }^{\mathrm{R} 24 \mathrm{C}}$ mouse model, specifically in the genesis of tumors in the pituitary and the endocrine pancreas.

\section{INTRODUCTION}

Multiple endocrine neoplasia (MEN) is clinically defined as a disorder with tumors arising in two or more different hormonal tissues $[1,2]$. MEN1 is an autosomal dominant cancer syndrome that is characterized by multiple tumors in the endocrine pancreas, the anterior pituitary and the parathyroid glands [1]. Inactivation of the MEN1 locus, that encodes the tumor suppressor protein 'menin', is the hallmark mutation that leads to MEN1 syndrome [3-5]. Menin is essential during development and disruption of both Men1 alleles in the mouse results in embryonic lethality thereby precluding analysis of its tumorigenesis potential [6]. Tissue-specific conditional inactivation of Menl in pancreatic islet $\beta$-cells, pituitary and in the parathyroid glands results in insulinomas, prolactinomas and parathyroid adenomas, respectively [79]. Taken together, these studies recapitulate the relevance 
of the MEN1 locus in suppression of endocrine tumors.

Like inactivation of menin, loss of the retinoblastoma $(\mathrm{RB})$ tumor suppressor protein promotes endocrine tumorigenesis. Mice heterozygous for $R B$ are predisposed to develop pituitary tumors, although $\mathrm{RB}$ inactivation results in less frequent development of endocrine pancreas and parathyroid tumors [10]. Mice heterozygous for both Menl and $R b 1$ alleles are predisposed to a high frequency of pancreatic hyperplasia and tumors of the intermediate pituitary suggestive of overlapping Menin and RB pathways in endocrine pancreas and pituitary tumorigenesis [11]. RB is a key regulator of the cell cycle and in its hypophosphorylated state restrains the E2F family of transcription factors that are required for DNA synthesis during the S-phase [12]. A cascade of cyclin-dependent kinases (Cdks) phosphorylates the eighteen serine/threonine residues of $\mathrm{Rb}$ and inactivates its tumor suppressor activity [13, 14]. Cdk activity is in turn inhibited by Cdk-inhibitors (CKI), such as the tumor suppressor p16Ink4a $[15,16]$. p16INK4a, encoded by the INK4A locus, is a key inhibitor of Cdk4 and a central effector of cellular senescence pathways [17].

Previously, we and others showed that $\mathrm{Cdk} 4$ is indispensable for embryonic [18] and post-natal development [19] and regeneration [20] of endocrine pancreatic islet $\beta$-cells and proliferation of cells of the anterior pituitary $[21,22]$. In contrast, inheritance of a p16 ${ }^{\text {Ink4a }}$-insensitive $C d k 4^{\text {Arg24Cys (R24C) }}$ allele, which results in an activated $\mathrm{Cdk} 4^{\mathrm{R} 24 \mathrm{C}}$, increased the transformation potential of cells and predisposed mice harboring this mutation to cancer due to loss of RB tumor suppressor function [19, 23, 24]. Further, a recent study showed that $\mathrm{Cdk} 4$, not $\mathrm{Cdk} 2$, is required for tumorigenic proliferation in the pituitary and pancreatic islets [25]. In addition, p $16^{\mathrm{INK} 4 \mathrm{a}}$ constrains islet cell proliferation and regeneration in an age-dependent manner [26], thus supporting the role of its substrate $\mathrm{Cdk} 4$ in regulating islet $\beta$-cell proliferation.

Along with inactivation of the $\mathrm{RB} / \mathrm{p} 16^{\mathrm{INK} 4 \mathrm{a}}$ pathway, activation of the enzyme telomerase is required to immortalize human epithelial cells [27]. In addition, loss of the three RB family members (RB, p107 and p130) leads to increased telomere length indicative of a role for RB family proteins in controlling telomere length [28]. Telomeres are specialized DNA elements that protect the ends of chromosomes from being recognized as DNA breaks from repair, recombination and degradation activities [29, 30]. However, ends of chromosomes continually lose the telomeres with each cell division due to incomplete replication of linear chromosomes by DNA polymerase. The ribonucleoprotein enzyme, telomerase, is responsible for adding new telomere repeats onto the 3 ' ends of chromosomes. Telomerase has two essential components: an enzymatic telomerase reverse transcriptase catalytic subunit (TERT) and an RNA component (TR or $T E R C$ ) that is used as a template in telomere synthesis.
Most normal somatic cells possess low or undetectable telomerase activity, whereas, highly proliferative cells and majority of cancer cells possess elevated telomerase activity. Much of our present knowledge about the in vivo role of telomerase is derived from studies using the telomerase-deficient mouse model $\left(m T R^{-/-}\right.$or $m T E R C^{-/-}$ mice) that was generated by elimination of the murine TR or TERC gene [31, 32] and the TERT $T^{-/}$mice [33-35]. Telomerase deficiency in combination with mutations in distinct tumor suppressor genes, except p53, significantly diminishes tumorigenesis potential [36-40] suggesting that telomerase inhibitors may be effective as anti-cancer agents [41-43]. Late-generation $m$ TERC $C^{-/-}$Ink4a/Arf mutant mice experienced a delayed tumor onset while maintaining the lymphoma and sarcoma spectrum [44]. In contrast, accelerated cancer onset and increased epithelial cancers were observed in late-generation $m T E R C^{-/-} p 53$ mutant mice [37].

To date, the role of telomerase activity in the pathogenesis of multiple endocrine neoplasia is unclear and the potential utility of telomerase inhibitor therapy for these cancers has not been explored. The $C d k 4^{\mathrm{R} 24 \mathrm{C}}$ mice are predisposed to increased incidence of endocrine pituitary tumors and, to a lesser extent, endocrine pancreatic adenomas [23, 24]. Here, using mice that harbor the $C d k 4^{\mathrm{R} 24 \mathrm{C} / \mathrm{R} 24 \mathrm{C}(\mathrm{R} / \mathrm{R})}$ mutation and inactivation of the mTERC locus, the $m T E R C^{-/-} C d k 4^{\mathrm{R} / \mathrm{R}}$ model, we have evaluated the consequence of RB pathway inactivation and telomere dysfunction on in vivo tumorigenesis. Due to their highly penetrant tumor development in the $C d k 4^{\mathrm{R} / \mathrm{R}}$ model, we have especially focused on development of neoplasia of the endocrine pituitary and pancreas. We demonstrate that telomere dysfunction reduces the incidence of endocrine anterior pituitary and islet pancreas tumors in the $m T E R C^{-/-}$ $C d k 4^{\mathrm{R} / \mathrm{R}}$ model. These results attest to an important role of telomerase activity in multiple endocrine neoplasias and support the utility of anti-telomerase inhibitors to target these tumors.

\section{RESULTS}

\section{Tumor progression in $\mathrm{Cdk}^{\mathrm{R} 24 \mathrm{C}}$ endocrine pancreas}

$\mathrm{Cdk} 4$ is essential for the post-natal development of pancreatic islet $\beta$-cells and proliferation of the anterior pituitary $[19,21,22]$. In contrast, the $C d k 4^{\mathrm{R} 24 \mathrm{C} / \mathrm{R} 24 \mathrm{C}}$ mice $\left(C d k 4^{\mathrm{R} / \mathrm{R}}\right.$ mice) are susceptible to increased tumor development within the pituitary and the endocrine pancreas $[23,24]$. To better stage the tumor progression, we performed histological analysis on pancreas sections from one-year old $C d k 4^{\mathrm{R} / \mathrm{R}}$ mice. These analyses revealed a distinct tumor development process in the endocrine pancreas; viz. (i) islet hyperplasia, (ii) islet adenomas, 
and infrequently, (iii) islet carcinomas (Figure 1). Abnormal localization of $\beta$-catenin is closely associated with carcinoma, tumor invasion and metastasis and poor survival and $\beta$-catenin localization is deregulated in human endocrine tumors [45]. $\beta$-catenin is transmembrane localized in normal cells, whereas in cancer cells, cytoplasmic or nuclear translocation of $\beta$-catenin is observed. Immunohistochemistry experiments indicated that $\beta$-catenin is localized to the membrane in hyperplastic endocrine islets in the $C d k 4^{R / R}$ pancreas (Figure 1), suggesting that majority of the cells at this stage were non-tumorigenic. In contrast, $\beta$-catenin was predominantly localized to the cytoplasm or nucleus in islet adenomas and rare islet carcinomas (Figure 1). Normal insulin immunoreactivity was observed in hyperplastic islets indicative of normal $\beta$-cell differentiation (Figure 1). In contrast, we observed a dramatic reduction of insulin staining in several regions within the islet adenomas and infiltrating islet carcinomas (Figure 1). Interestingly, we observed an inverse correlation between $\beta$-catenin localization and insulin expression. Normal insulin expressing cells within the hyperplastic islets exclusively contained membrane localized $\beta$-catenin. In contrast, the cytoplasmic or nuclear $\beta$-catenin observed in islet adenomas and carcinomas was accompanied with dramatic loss of insulin expression indicative of a tumorigenic transition.

\section{Elevated telomerase activity and increased telomere length in $\boldsymbol{C d k} 4^{\mathrm{R} 24 \mathrm{C}}$ cells}

Telomerase activation is correlated with the ability of cells to escape senescence, undergo immortalization and be susceptible to transformation [46]. We examined whether telomerase activity played a role in the $C d k 4^{\mathrm{R} R}$ islet tumorigenesis model. Pancreas were harvested from old (>12 months of age) $C d k 4^{+/+}$and $C d k 4^{R / R}$ mice and islets were isolated for analysis of telomerase activity. We observed a significantly elevated telomerase activity in $C d k 4^{R / R}$ islets compared to islets isolated from comparatively old-aged $C d k 4^{+/+}$mice (Figure 2A) suggestive of a role for telomerase in islet tumorigenesis.

To better characterize the role of telomerase in the $C d k 4^{R / R}$ model we performed studies with $C d k 4^{R / R}$ mouse embryonic fibroblasts (MEFs). We and others previously showed that $C d k 4^{R / R}$ MEFs escape cellular senescence, get immortalized upon repeated passage in culture and are susceptible to oncogenic transformation $[23,24]$. To determine the role of telomerase in their transformation potential, we monitored telomere length and telomerase activity in $C d k 4^{R / R}$ MEFs. We detected a significantly elevated telomerase activity in $C d k 4^{R / R}$ MEFs compared to that observed in $\mathrm{Cdk}^{+/+}$MEFs (Figure 2B). Further, telomere based fluorescence in situ hybridization (FISH) analysis revealed an increased telomere length in $C d k 4^{R / R}$ MEFs compared to that observed in $C d k 4^{+++}$MEFs (data
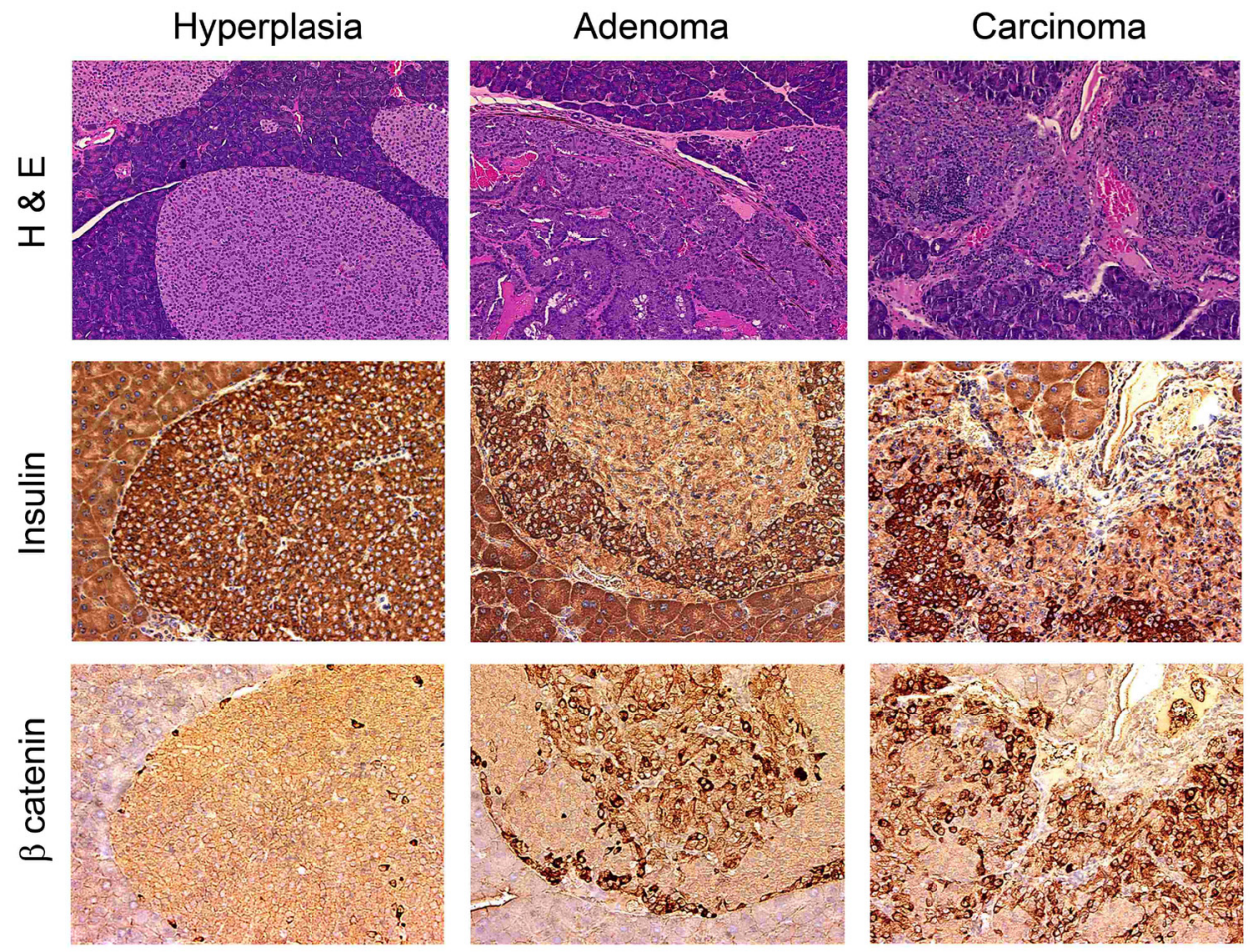

Figure 1: Tumor progression in $\boldsymbol{C} \boldsymbol{d} \boldsymbol{k} \boldsymbol{4}^{\mathrm{R} / \mathrm{R}}$ pancreas. H\&E staining and immunostaining (brown) for insulin and $\beta$-catenin in different pancreatic tumor stages from 12-month old $C d k 4^{\mathrm{R} / \mathrm{R}}$ mice. 
not shown).

\section{Generation of mTERC null and $C d k 4^{\mathrm{R} 24 \mathrm{C} / \mathrm{R} 24 \mathrm{C}}$ mutant mice ( $m T E R C^{-/} C d k 4^{R / R}$ mice)}

The elevated telomerase activity in $C d k 4^{\mathrm{R} / \mathrm{R}} \mathrm{MEFs}$ and islets are consistent with an important role for telomere biology in $C d k 4^{\mathrm{R} 24 \mathrm{C}}$ driven cellular transformation and in vivo tumorigenesis. In order to directly examine the contribution of telomerase in this tumor model, we generated mice that (i) harbor the $C d k 4^{\mathrm{R} 24 \mathrm{C}}$ mutation, and, (ii) that are null for the essential RNA component of mouse telomerase ( $m T E R C^{-/-} C d k 4^{\mathrm{R} / \mathrm{R}}$ mice). To achieve this, we mated second generation, G2, $m T E R C^{-/-}$mice [31] with $C d k 4^{\mathrm{R} / \mathrm{R}}$ mice [19] to first derive heterozygous $m T E R C^{+/-}$ $C d k 4^{+/ R}$ mice that were subsequently inter-bred to produce G2, G3, G4, G5 and G6 $m$ TER $C^{-/-} C d k 4^{\mathrm{R} / \mathrm{R}}$ and $m T E R C^{+/+}$ $C d k 4^{\mathrm{R} / \mathrm{R}}$ mice (Figure 2C). Diminished fertility precluded the derivation of subsequent generations of $m T E R C^{-/-}$
$C d k 4^{\mathrm{R} / \mathrm{R}}$ and $m T E R C^{+/+} C d k 4^{\mathrm{R} / \mathrm{R}}$ mice. All experiments outlined in this manuscript have been performed on age and sex matched G5-G6, mTER $C^{-/-} C d k 4^{\mathrm{R} / \mathrm{R}}$ and $m T E R C^{+/+}$ $C d k 4^{\mathrm{R} / \mathrm{R}}$ mice.

\section{Growth characteristics of $\boldsymbol{m} T E R C^{/-} C d k 4^{R / R}$ mouse embryo fibroblasts}

To evaluate the contribution of telomere dysfunction on $C d k 4^{\mathrm{R} 24 \mathrm{C}}$ driven immortalization capacity and transformation potential, we generated MEFs from G5 $m$ TERC $C^{-/-} C d k 4^{\mathrm{R} / \mathrm{R}}$ and $m T E R C^{+/+} C d k 4^{\mathrm{R} / \mathrm{R}}$ mice. Quantitative fluorescence in situ hybridization (Q-FISH) on MEFs from $m T E R C^{-/-} C d k 4^{\mathrm{R} / \mathrm{R}}$ showed evidence of decreased telomere length compared to $m T E R C^{+/+} C d k 4^{R / R}$ MEFs ( $p=0.08$, Figure 2D). As expected, the telomere length in $m T E R C^{-/-} C d k 4^{\mathrm{R} / \mathrm{R}}$ MEFs was similar to the telomere length observed in $m T E R C^{-/-} C_{k} 4^{+/+}$MEFs (Figure 2D). These results indicate that the telomere
A

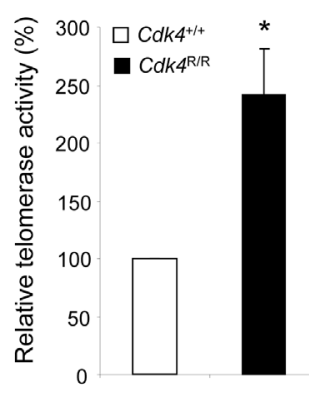

D

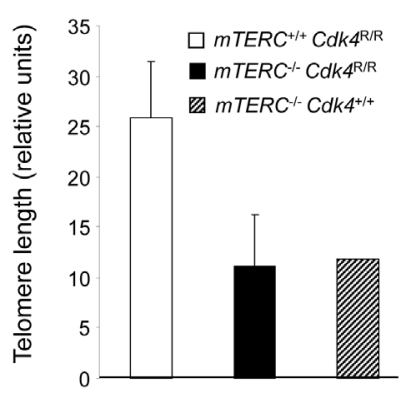

B

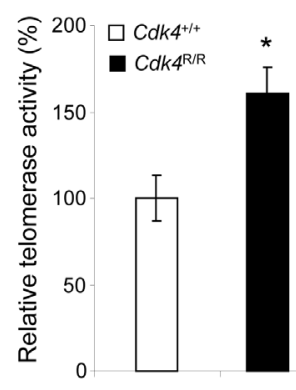

$\mathbf{E}$

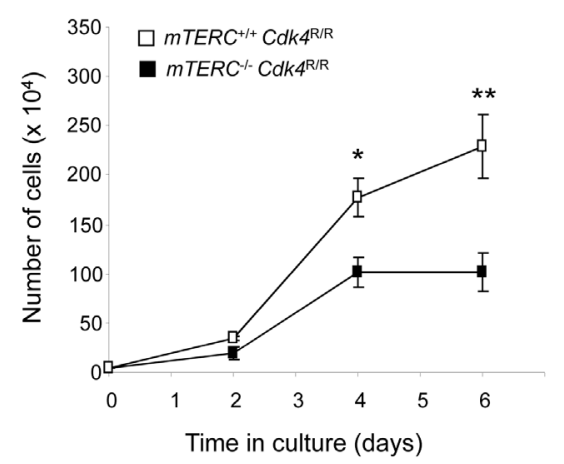

C

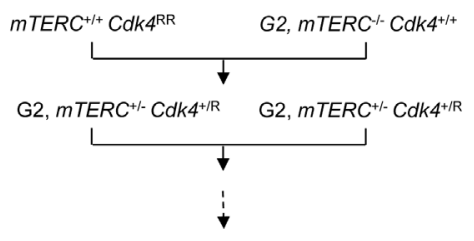

G3, G4, G5 and G6

$m T E R C^{+/+} C d k 4^{R / R}, \quad m T E R C^{-1-} C d k 4^{R / R}$
$\mathbf{F}$

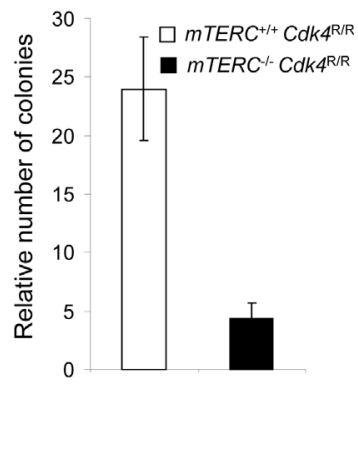

Figure 2: Role of telomerase activity in $\boldsymbol{C d} \boldsymbol{k} \boldsymbol{4}^{\mathrm{R} / \mathrm{R}}$ mediated cell proliferation and transformation. Telomerase Activity in islets $(A)$ and MEFs $(B)$ from $C d k 4^{+/+}$(open boxes) and $C d k 4^{\mathrm{R} / \mathrm{R}}$ (closed boxes) mice. TRAP assay was performed using $500 \mathrm{ng}$ of protein from islets of 17 month old mice and from MEF cell lysate. $(C)$ Mating scheme to generate $m T E R C^{-/-} C d k 4^{\mathrm{R} / \mathrm{R}}$ and $m T E R C^{+/+} C d k 4^{\mathrm{R} / \mathrm{R}}$ mice. Mating of $C d k 4^{R / R}$ mice with G2 $m T E R C^{-/}$mice produced heterozygous $m T E R C^{-/+} \mathrm{Cdk} 4^{+/ R}$ mice and subsequently generationally aged $m T E R C^{-/-} C d k 4^{R / R}$ and $m T E R C^{+/+} C d k 4^{R / R}$ mice. (D) Average telomere length (in relative fluorescent units) of metaphase from MEF cultures from $m T E R C^{+/+} C d k 4^{\mathrm{R} / \mathrm{R}}$ (open box), $m T E R C^{-/-} C d k 4^{\mathrm{R} / \mathrm{R}}$ (closed box) and $m T E R C^{-/-} C d k 4^{+/+}$(hashed box) mice as determined by Q-FISH. (E) Proliferation curves of $m T E R C^{-/-} C d k 4^{R / R}$ (closed boxes) and $m T E R C^{+/+} C d k 4^{R / R}$ (open boxes) MEFs. (F) Colony formation following seeding at 3500 cells of $m T E R C^{-/-} C d k 4^{\mathrm{R} / \mathrm{R}}$ (closed boxes) and $m T E R C^{+/+} C d k 4^{\mathrm{R} / \mathrm{R}}$ (open boxes) MEFs per 6 well plate and 14 days of culture. All data presented in experiments shown in each figure panel here represents the mean of at least three independent experiments and along standard error of mean. Statistical analysis was performed by student t-test. 
Table 1. Cytogenetic profiles in $m T E R C^{+/+} C d k 4^{R R}, m T E R C^{-/} C d k 4^{R R}$ and $m T E R C^{-/} C d k 4^{+/+}$fibroblast cultures

\begin{tabular}{|c|c|c|c|c|c|c|c|c|c|}
\hline Culture & Passage & $\begin{array}{l}\text { Metaphases } \\
\text { Examined } \\
\text { (chromosomes) }\end{array}$ & $\begin{array}{l}\text { Average } \\
\text { chromo. no. } \\
\text { (major ploidy) }\end{array}$ & $\begin{array}{l}\text { Percent } \\
\text { Metaphases } \\
\text { (other ploidy) }\end{array}$ & $\begin{array}{l}\text { Rb-like } \\
\text { fusions (\% } \\
\text { metaphases) }\end{array}$ & $\begin{array}{l}\text { Tri-multi radial } \\
\text { chromo. } \\
\text { involved }\end{array}$ & $\begin{array}{l}\text { non-reciprocal } \\
\text { translocation/ } \\
\text { metaphase }\end{array}$ & $\begin{array}{l}\text { Fragments } \\
\text { (hsr,dm) } \\
\text { /metaphase }\end{array}$ & $\begin{array}{l}\text { Average telomere } \\
\text { length } \\
\text { (relative units) }\end{array}$ \\
\hline mTERC ${ }^{+/+} C d k 4^{R R} \# 1$ & 24 & $13(597)$ & $40(2 n)$ & $33(4 n)$ & 33 & 4.4 & 0.10 & 0.10 & 12.3 \\
\hline$m T E R C^{+/+} C d k 4^{R R} \# 2$ & 26 & 24 (1323) & $124(6 n)$ & $43(4 n)$ & 57 & 7.5 & 0.17 & 0.58 & 34.5 \\
\hline$m T E R C^{++} C d k 4^{R R} \# 3$ & 24 & $20(868)$ & $39(2 n)$ & $47(4 n)$ & 80 & 10.4 & 0 & 0.07 & 27.7 \\
\hline$m T E R C^{+/+} C d k 4^{R R} \# 4$ & 26 & 20 (989) & $81(4 n)$ & $33(6 n)$ & 100 & 11.9 & 0.10 & 0.50 & 29.2 \\
\hline mTERC ${ }^{--} C d k 4^{R R} \# 1$ & 23 & $17(865)$ & $77(4 n)$ & $44(6 n)$ & 100 & 19.3 & 0.22 & 0 & 10.7 \\
\hline$m T E R C^{-1-} C d k 4^{k \kappa} \# 2$ & 23 & $20(852)$ & $74(4 n)$ & $35(6 n)$ & 100 & $>60$ & 1.25 & 0 & 18.6 \\
\hline$m T E R C^{-l-} C d k 4^{R R} \# 3$ & 23 & $20(885)$ & $77(4 n)$ & $15(2 n)$ & 85 & 16.2 & 0.15 & 0 & 4.4 \\
\hline mTERC $C^{-/-} \mathrm{Cdk}^{+/+}$ & 24 & $24(329)$ & $41(2 n)$ & $8(4 n)$ & 100 & 2.7 & 0 & 0.25 & 11.8 \\
\hline
\end{tabular}
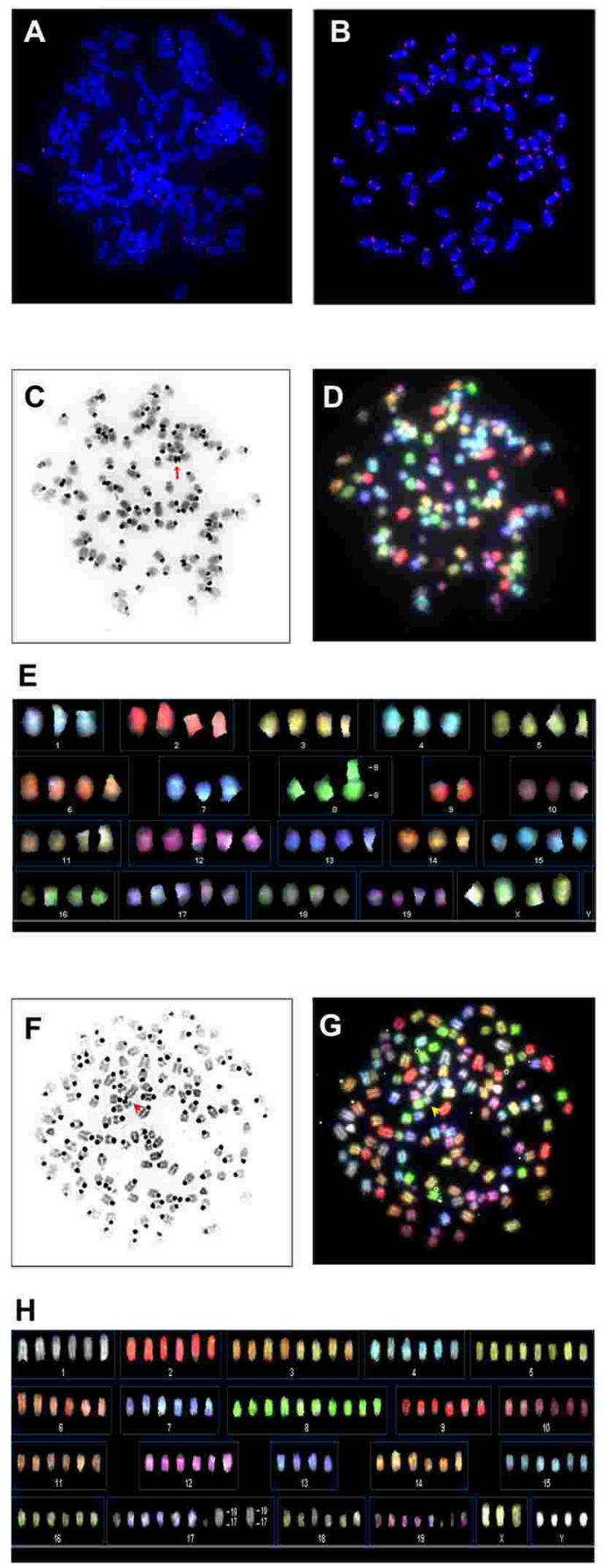

length in $C d k 4^{\mathrm{R} / \mathrm{R}}$ MEFs was most likely dependent on the elevated telomerase activity (Fig. 1B).

We next evaluated the cell growth properties and transformation potential of $C d k 4^{\mathrm{R} / \mathrm{R}} \mathrm{MEFs}$ in the context of telomere dysfunction. $C d k 4^{\mathrm{R} / \mathrm{R}}$ cells can escape senescence and can be easily immortalized in culture [23]. All the assayed $m T E R C^{-/-} C d k 4^{\mathrm{R} / \mathrm{R}}$ and $m T E R C^{+/+} C d k 4^{\mathrm{R} / \mathrm{R}} \mathrm{MEF}$ cultures were able to escape senescence upon repeat passage on a 3T3 protocol (data not shown). When assayed for their ability to proliferate in a continuous culture, we observed that $m T E R C^{-/} C d k 4^{\mathrm{R} / \mathrm{R}}$ cells exhibited a reduced growth rate compared to $m T E R C^{+/+} C d k 4^{\mathrm{R} / \mathrm{R}}$ cells (Figure 2E). Actively transformed cells become growth factor independent that allows them to survive effectively in a low density seeded culture and proliferate efficiently to form colonies of cells. In contrast, non-transformed cells or cells with reduced transformation potential will remain growth arrested or maintain a reduced rate of proliferation in a low density culture and fail to form colonies. To evaluate their ability to proliferate as single cells beyond the senescence checkpoint and to compare their relative transformation potential, we next examined the ability of the $m T E R C^{+/+} C d k 4^{\mathrm{R} / \mathrm{R}}$ and $m T E R C^{-/-} C d k 4^{\mathrm{R} / \mathrm{R}}$ MEFs to grow in a low density culture (Figure $2 \mathrm{~F}$ ). Significantly reduced numbers of colonies were observed when the $m T E R C^{-/-} C d k 4^{R / R}$ MEF cells $(4.3 \pm 1.4$ colonies; $\mathrm{p}<0.001)$ were grown in a low density culture compared to $m T E R C^{+/+} C d k 4^{\mathrm{R} / \mathrm{R}}$ MEFs $(24.0 \pm 4.4$ colonies $)$. These results are suggestive of reduced transformation potential of $m T E R C^{-1} C d k 4^{\mathrm{R} / \mathrm{R}} \mathrm{MEF}$ cells.

Figure 3: Representative telomere fluorescence of metaphase chromosomes from $\boldsymbol{m}$ TER $\boldsymbol{C}^{-/-} \boldsymbol{C d k}^{\mathrm{R} / \mathrm{R}}(A)$ and $\boldsymbol{m} \boldsymbol{T E R} C^{+/+} \boldsymbol{C d k}^{\mathrm{R} / \mathrm{R}}$ (B) MEFs. Chromosomes were stained with DAPI (blue), and telomeric DNA was detected by FISH with Cy3-conjugated TTAGGG nucleic acid probe (red). Spectral karyotyping $(D, E$ and $G, H)$ shows chromosomal fusion and aneuploidy. Reverse DAPI image of the same metaphase as in $D$ and $G$ are shown in $C$ and $F$. Arrow in $\mathrm{C}$ indicates $\mathrm{Rb}-$ like fusion. Arrows in $F$ and $G$ show examples of multi-radial chromosomes. Panels shown in $C, D, E$ represent $m T E R C^{-1-}$ $C d k 4^{R / R}$ and those in $F, G, H$ represent $m T E R C^{+/+} C d k 4^{R / R}$. 
Table 2. Characterization of tumors in $m T E R C C d k 4^{\mathrm{R} 24 \mathrm{C}}$ mutant mice

\begin{tabular}{|c|c|c|c|c|c|c|}
\hline & \multicolumn{3}{|c|}{$m T E R C^{+/+} C d k 4^{R R}$} & \multicolumn{3}{|c|}{$m T E R C^{-1-} C d k 4^{R R}$} \\
\hline & Male & Female & Total & Male & Female & Total \\
\hline Number of animals & 7 & 20 & 27 & 13 & 19 & 32 \\
\hline \multicolumn{7}{|l|}{ Tumor initiation } \\
\hline Animals with tumors ( $\%$ of total animals) & 7 & 18 & $25(93 \%)$ & 7 & 11 & $18(56 \%)$ \\
\hline Primary tumors (tumor/animal) & 20 & 43 & $63(2.33)$ & 12 & 19 & $31(0.97)$ \\
\hline Animals with multiple tumors ( $\%$ of total animals) & 6 & 12 & $18(67 \%)$ & 2 & 6 & $8(25 \%)$ \\
\hline \multicolumn{7}{|l|}{ Tumor progression } \\
\hline Benign tumors (\% of total tumors) & 13 & 26 & $39(62 \%)$ & 9 & 11 & $20(65 \%)$ \\
\hline Non-metastatic malignant tumors ( $\%$ of total tumors) & 7 & 17 & $24(38 \%)$ & 3 & 8 & $11(36 \%)$ \\
\hline Metastatic malignant tumors (\% of total tumors) & 2 & 4 & $6(10 \%)$ & 0 & 3 & $3(10 \%)$ \\
\hline
\end{tabular}

Next, we performed cytogenetic analyses of $m T E R C^{-/-} C d k 4^{\mathrm{R} R}$ and $m T E R C^{+/+} C d k 4^{R / R}$ MEFs to determine the effect of telomere dysfunction on chromosomal aberrations in $C d k 4^{R / R}$ cells (Table 1). The average chromosomal number for a major ploidy was $2 \mathrm{n}$

A
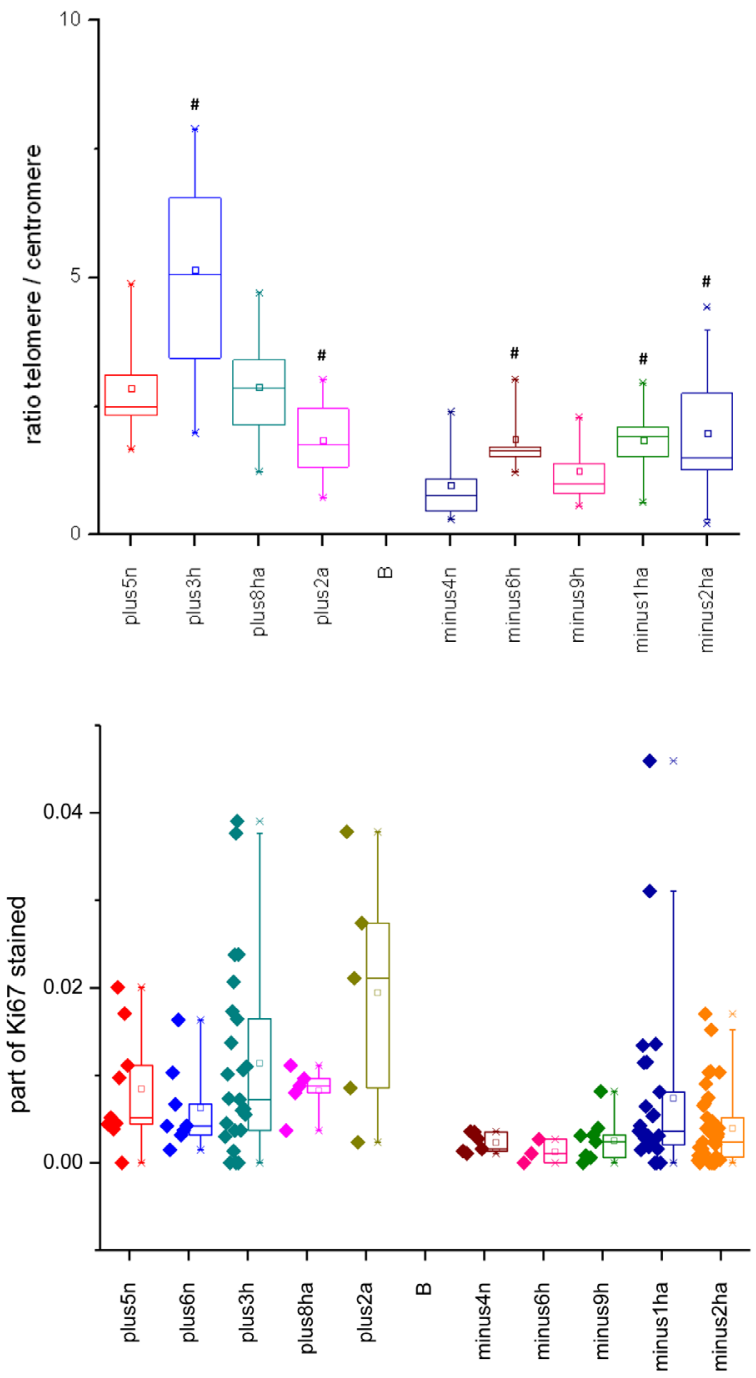

in $m T E R C^{-/ /} C d k 4^{+/+}$and $m T E R C^{+/+} C d k 4^{+/+}$cells suggesting that telomere dysfunction does not result in aneuploidy (data not shown). In contrast, inheritance of the $C d k 4^{\mathrm{R} 24 \mathrm{C}}$ mutation in $m T E R C^{+/+} C d k 4^{R / R}$ and $m T E R C^{-/} C d k 4^{R / R}$ cells resulted in $4 \mathrm{n}$ or $6 \mathrm{n}$ as the average chromosomal number for a major ploidy. In addition, majority of $m T E R C^{+/+}$ $C d k 4^{R / R}$ and $m T E R C^{-/-} C d k 4^{R / R}$ cells presented a high percentage of metaphases (between 33-47\%) with other ploidy (4n or $6 n$ ). Together, these results are illustrative of $C d k 4^{\mathrm{R} 24 \mathrm{C}}$ mediated increase in aneuploidy. Additionally, the $C d k 4^{\mathrm{R} 24 \mathrm{C}}$ mutation leads to infrequent chromosomal rearrangements referred to as "sticky ends" that include three types of events: end-end associations, p-p or q-q or $\mathrm{p}$-q fusions and Rb-like fusion (Table 1, Figure 3). We observed that inheritance of the $m T E R C^{-/}$background, in the $m T E R C^{-/} C d k 4^{R / R}$ cells, increased the frequency of "sticky ends". In addition, we found that the number of nonreciprocal translocations were also higher in $m T E R C^{-/-}$ $C d k 4^{\mathrm{R} R}$ cells $(0.54 \pm 0.43$ per metaphase $)$ compared to 0.090 .04 per metaphase in $m T E R C^{+/+} C d k 4^{\text {RR }}$ cells (Table 1). Expectedly, the frequency of Robertsonian fusions -

Figure 4: Telomere length and proliferation in islets from $m T E R C^{/-} C d k 4^{\mathrm{R} / \mathrm{R}}$ and $m T E R C^{+/+} C d k 4^{\mathrm{R} / \mathrm{R}}$ mice. (A) Telomere length was analyzed in pancreatic islets from 4 telomerase positive and 5 negative mice. In each sample 8-22 islets were scored. In each islet, a ratio between telomere and centromere signal in phantom areas, which size was approximately equal to the size of cells was measured and the mean values is shown in the box chart plot. (B) And the same sample sections as for telomere length analysis were stained with $\mathrm{Ki}-67$, insulin and DAPI antibodies. The total number of $8 \mu \mathrm{m}$ diameter circle-phantoms containing DAPI staining was calculated, which approximately corresponded to cell number (C). Then we estimated the number of the phantoms, which had Ki-67 staining $(\mathrm{K})$. The part of stained cells was calculated as $\mathrm{P}=\mathrm{K} / \mathrm{C}$ and plotted on Y-axis for each islet. Statistical analysis for the ratio of telomere/centromere was done by ANOVA test. * indicates a value different from the normal islet in each group with a $p<0.05$. Note: $\mathrm{n}=$ normal; $\mathrm{h}=$ hyperplasia; $\mathrm{a}=$ adenoma; plus $=$ telomerase positive; minus $=$ telomerase negative. 
Table 3. Telomere dysfunction suppresses tumorigenesis in $\mathrm{Cdk}^{\mathrm{R} 24 \mathrm{C}}$ mutant mice

\begin{tabular}{|c|c|c|c|c|}
\hline \multirow[t]{2}{*}{ Anatomic site, tumor type } & \multicolumn{2}{|c|}{ mTERC $^{+/+}$CdK4 $^{\mathrm{RR}(\mathrm{a})}$} & \multicolumn{2}{|c|}{$\mathrm{mTERC}^{/-} \mathrm{Cdk4^{ \textrm {RR } ( \mathrm { b } ) }}$} \\
\hline & Incidence & Percentage & Incidence & Percentage \\
\hline $\begin{array}{l}\text { Adrenal, cortical } \\
\text { carcinoma }\end{array}$ & $0 / 27$ & 0 & $3 / 32$ & 9.4 \\
\hline $\begin{array}{c}\text { Adrenal, } \\
\text { pheochromocytoma }\end{array}$ & $2 / 27$ & 7.4 & $1 / 32$ & 3.1 \\
\hline $\begin{array}{l}\text { Hemangiosarcoma, } \\
\text { various organs } *\end{array}$ & $11 / 27$ & 41 & $4 / 32$ & 12.5 \\
\hline Lung, adenoma, alveolar & $1 / 27$ & 3.7 & $2 / 32$ & 6.3 \\
\hline Lung, carcinoma, alveolar & $2 / 27$ & 7.4 & $0 / 32$ & 0 \\
\hline $\begin{array}{c}\text { Pancreas, islet cell } \\
\text { adenoma + carcinoma }\end{array}$ & $16 / 27$ & 59 & $6 / 32$ & 19 \\
\hline $\begin{array}{c}\text { Pituitary, adenoma + } \\
\text { carcinoma }\end{array}$ & $17 / 19$ & 89 & $5 / 25$ & 20 \\
\hline $\begin{array}{l}\text { Testis, interstitial cell } \\
\text { tumor }\end{array}$ & $3 / 7$ & 43 & $1 / 13$ & 7.7 \\
\hline
\end{tabular}

* Liver, spleen, skin, mesenteric lymph node, heart, skeletal muscle, uterus.

${ }^{\text {a }}$ Other neoplasma $(n=1)$ in females are Harderian gland adenoma, Follicular center cell lymphoma, mammary glandular carcinoma, vertebral osteosarcoma and cutaneous sarcoma $(n=2)$.

${ }^{b}$ Other neoplasms ( $n=1$ ) in females are histiocytic sarcoma, cecum adenoma and cutaneous sarcoma, in males, thymoma.

a hallmark of telomere dysfunction - increased to $95.0 \%$ \pm 6.1 in $m T E R C^{--} C d k 4^{R / R}$ cells from $67.5 \% \pm 16.7$ in $m T E R C^{+/+} C d k 4^{R / R}$ cells (Table 1). Further, the frequency of chromosomes involved in tri and multi-radial fusion increased in $m T E R C^{-1-} C d k 4^{R / R}$ cells $(31.8 \% \pm 17.3)$ compared to $8.6 \% \pm 1.9$ in $m T E R C^{+/+} C d k 4^{\text {R/R }}$ cells (Table 1). Taken together, we conclude that inheritance of the $C d k 4^{\mathrm{R} 24 \mathrm{C}}$ mutation leads to aneuploidy and chromosomal aberrations that synergize with the cytogenetic abnormalities incurred due to telomere dysfunction.

\section{Reduced telomere length and proliferative

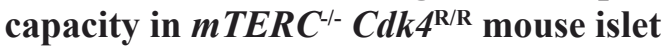

We next examined the telomere length and proliferation capacity in normal, hyperplastic and adenomatous islets from $m T E R C^{+/+} C d k 4^{\mathrm{RR}}$ and $m T E R C^{-/-}$ $C d k 4^{R / R}$ mice to evaluate the role of telomere dysfunction on endocrine pancreatic tumorigenesis. The telomere/ centromere ratios in the $m T E R C^{+/+} C d k 4^{R / R}$ mice were found to be higher than those observed in the $m T E R C^{-1-}$ $C d k 4^{R / R}$ mice (Fig. 4A). In the $m T E R C^{+/+} C d k 4^{R / R}$ mice, the ratio of telomere/centromere in the hyperplastic sample (plus3h) is increased suggesting that telomeres are elongated, perhaps via telomerase activation. In contrast in the adenomatous sample (plus2a), the telomere/centromere ratio was reduced probably due to active proliferation (Fig. 4B), thus reducing telomere length. Further, this also suggests absence of telomeraseindependent mechanisms in the $m T E R C^{+/+} C d k 4^{\mathrm{R} / \mathrm{R}}$ sample. Interestingly, the variation in centromere and telomere intensities between phantoms within one islet (both, in hyperplastic and adenomatous samples) was higher than that seen in the normal sample (plus5n). These observations suggest that in addition to telomere length, possibly the chromosome number varies in these samples. In the $m T E R C^{-/} C d k 4^{R / R}$ samples, hyperplastic and especially hyperplastic/adenomatous samples showed increase of telomere/centromere ratio (Fig. 4A). These data suggest support the plausible existence of telomeraseindependent mechanisms contributing to the increased telomere length (Fig. 4A) and increased cell proliferation (Fig. 4B) in the hyperplastic/adenomatous samples from the $m T E R C^{-/-} C d k 4^{\mathrm{RR}}$ mice.

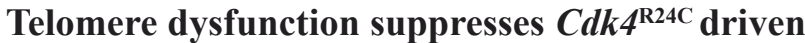 pituitary and endocrine pancreas neoplasia}

Mice inheriting the $C d k 4^{\mathrm{R} 24 \mathrm{C}}$ allele exhibit high rates of pituitary tumors and endocrine pancreas adenomas and, in addition, are susceptible to tumor development in other organs, specifically hemangiosarcomas $[23,24]$. In order to appreciate the role of telomere dysfunction on $C d k 4^{\mathrm{R} 24 \mathrm{C}}$ driven tumorigenesis, we characterized development of spontaneous tumors in G5-G6, mTERC $C^{--} C d k 4^{\mathrm{R} R}$ and G5-G6, $m T E R C^{+/+} C d k 4^{R / R}$ mice (hereafter referred to as $m T E R C^{-/} C d k 4^{\mathrm{R} R \mathrm{R}}$ and $m T E R C^{+/+} C d k 4^{\mathrm{R} / \mathrm{R}}$ mice). Cohorts of mice were evaluated for two years and subjected to histopathology analysis to determine the incidence and types of tumors. These analyses revealed that spontaneous 
Table 4. Pancreatic and pituitary tumors in $m T E R C C d k 4^{\mathrm{R} 24 \mathrm{C}}$ mutant mice

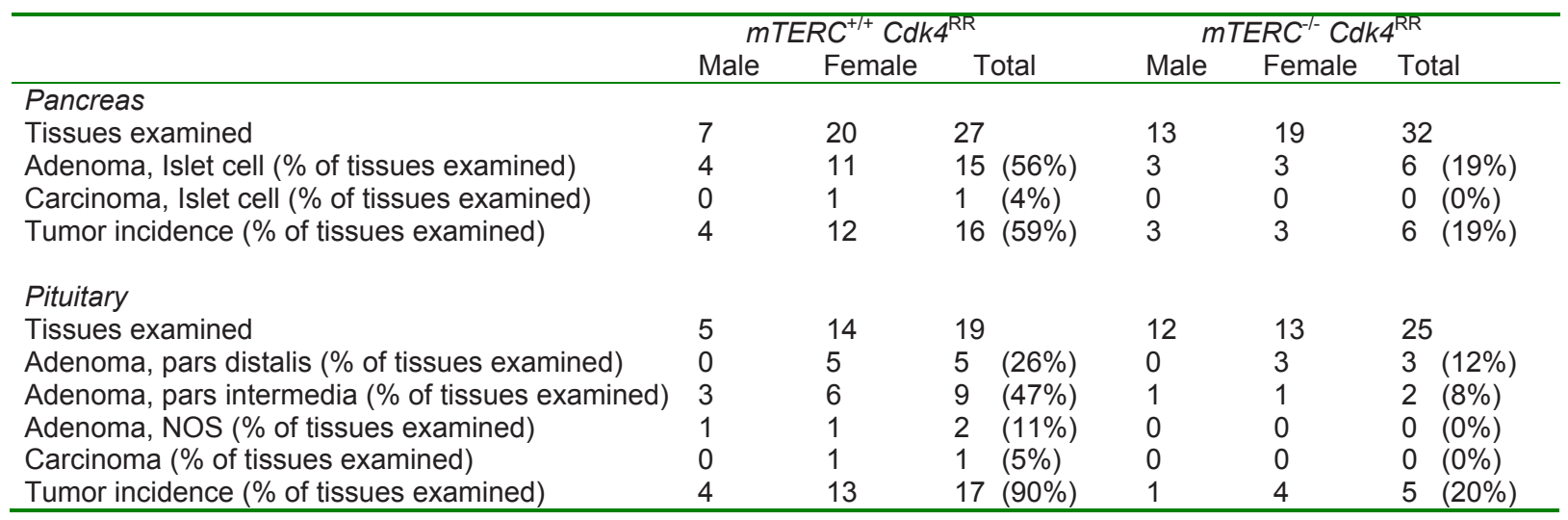

A

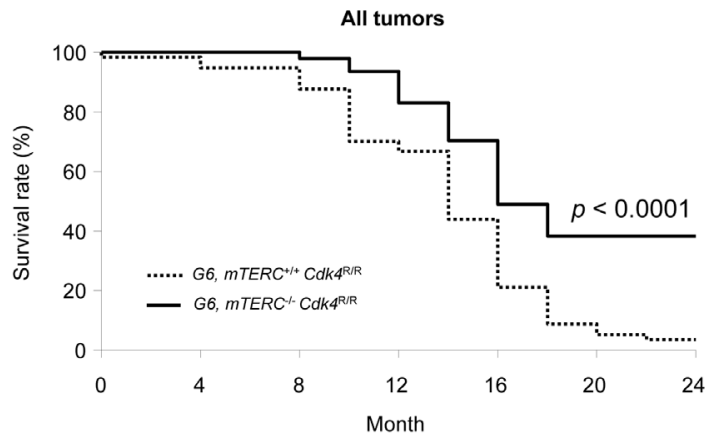

B

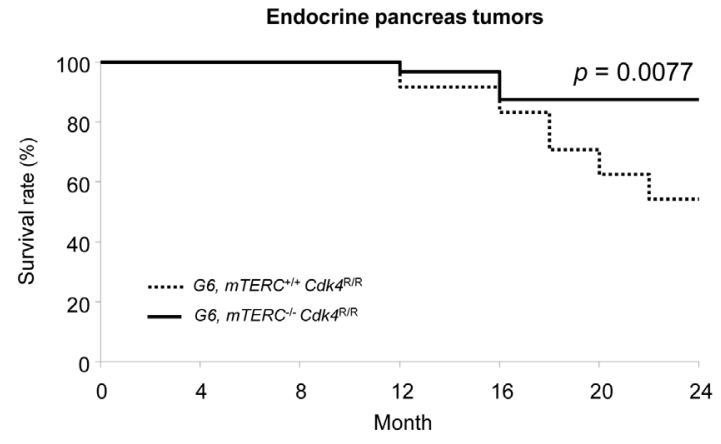

C

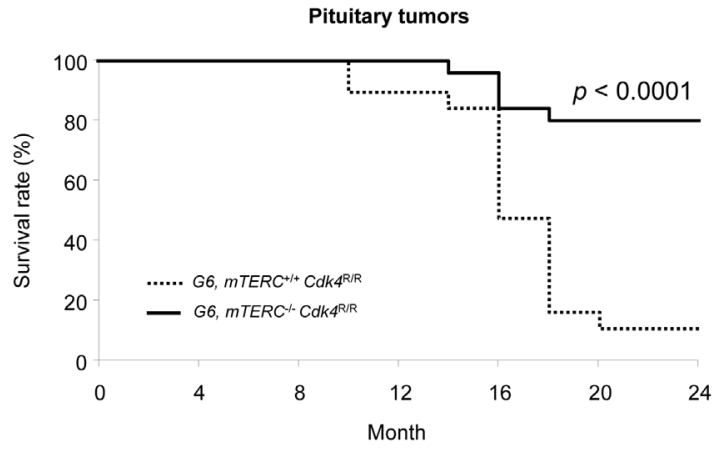

neoplasms occurred in both groups of mice, $m T E R C^{-1}$ $C d k 4^{\mathrm{R} / \mathrm{R}}$ and $m T E R C^{+/+} C d k 4^{\mathrm{R} / \mathrm{R}}$. Interestingly, we observed significantly reduced tumor development in the $m T E R C^{-1-}$ $C d k 4^{\mathrm{R} / \mathrm{R}}$ group (29 of 47 mice; $62 \%$ ), compared to the high tumor incidence in the $m T E R C^{+/+} C d k 4^{R / R}$ group ( 55 of 57 mice; 97\%). According to the log-rank test, we observed a significant difference between the two groups $(p<0.0001)$. Kaplan-Meier estimation analysis revealed that the reduction in tumor incidence was correlated with an increase in survival (Figure 5A).

A subset of mice in both groups, $m T E R C^{+/+} C d k 4^{R / R}$ $(\mathrm{n}=27)$ and $m T E R C^{-/-} C d k 4^{R / R}(\mathrm{n}=32)$ was subjected to further comprehensive analysis. As shown in Table 2, these analyses revealed that the total number of primary neoplasms was reduced in $m T E R C^{-/-} C d k 4^{R / R}$ mice (31 neoplasms in 32 mice; 18/32, 56\% mice with neoplasms) compared to $m T E R C^{+/+} C d k 4^{\mathrm{R} / \mathrm{R}}$ mice (63 neoplasms in 27 mice; 25/27, 93\% mice with neoplasms). Further, as shown in Table 2, we observed a reduction in the multiplicity of tumors in $m T E R C^{-/} C d k 4^{\mathrm{R} / \mathrm{R}}$ mice $(8 / 32$ mice; $25 \%$ mice) compared to that seen in the $m T E R C^{+/+}$

Figure 5: Kaplan-Meier analysis of tumor incidence in late generation $m T E R C^{/-} C_{d k 4^{\mathrm{R} / \mathrm{R}}}$ and $m T E R C^{+/+}$ $\boldsymbol{C d} \boldsymbol{k}^{\mathrm{R} / \mathrm{R}}$ mice. (A) Spontaneous tumors were diagnosed by macroscopic and microscopic observation for total tumor incidence. $47 \mathrm{mTERC}^{/ /} \mathrm{Cdk}^{\mathrm{RR}}$ mice and $57 \mathrm{mTERC^{+/+ }} C d \mathrm{k}^{\mathrm{RRR}}$ mice were analyzed for total spontaneous tumor incidence. Mice with multiple tumors were counted once. Telomere dysfunction suppresses the incidence and delays the onset of endocrine pancreatic tumors $(B)$ and pituitary tumors $(C)$ in $m T E R C^{-1-}$ $C d k 4^{R / R}$ mice. Pancreatic and pituitary tumors were diagnosed histologically. $m T E R C^{-/} C d k 4^{R / R}(\mathrm{n}=32)$ and $m T E R C^{H /+} C d k 4^{R / R}$ $(\mathrm{n}=27)$ mice were analyzed for pancreatic tumors and $m T E R C^{-1-}$ $C d k k^{R / R}(\mathrm{n}=25) \mathrm{s}$ from mT $m T E R C^{+/+} C d k 4^{R / R}(\mathrm{n}=19)$ mice were analyzed for pituitary tumors. Statistical analysis was done by the log-rank test using SAS 9.1 program (SAS Institute Inc., Cary,NC). 
$C d k 4^{\mathrm{R} / \mathrm{R}}$ mice $(18 / 27 ; 67 \%$ mice). Interestingly, the average age for tumor development was increased in $m T E R C^{/-}$ $C d k 4^{\mathrm{R} / \mathrm{R}}$ mice (males, 368 days and females, 423 days) compared to $m T E R C^{+/+} C d k 4^{\mathrm{R} / \mathrm{R}}$ mice (males, 307 days and females, 408 days). Together, these observation are indicative of reduced and delayed tumor initiation in the $m T E R C^{-/-} C d k 4^{\mathrm{R} / \mathrm{R}}$ mice compared to $m T E R C^{+/+} C d k 4^{\mathrm{R} / \mathrm{R}}$ mice.

Despite a reduction in tumor incidence, the histological appearance (tumor grade and severity) of the $m T E R C^{-/-} C d k 4^{\mathrm{R} / \mathrm{R}}$ tumors analyzed was indistinguishable from that of the $m T E R C^{+/+} C d k 4^{R / R}$ tumors. Further, as seen in Table 2, once tumor initiation occurred, the proportion of benign and malignant tumors were similar in the $m$ TERC $C^{-/} C_{k} 4^{\mathrm{R} / \mathrm{R}}$ mice $(20 / 31 ; 65 \%$ benign and $11 / 31$; $36 \%$ malignant) and $m$ TER $C^{+/+} C d k 4^{\mathrm{R} / \mathrm{R}}$ mice $(39 / 63 ; 62 \%$ benign and $24 / 63 ; 38 \%$ malignant). Also, the number of malignant neoplasms that were metastatic was similar in $m T E R C^{-/-} C d k 4^{\mathrm{R} / \mathrm{R}}$ mice (3 in 31 tumors; 10\%) compared to $m T E R C^{+/+} C d k 4^{\mathrm{R} / \mathrm{R}}$ mice (6 in 63 tumors; $10 \%$ ). These results are suggestive of similar progression of established tumors in the $m T E R C^{-/-} C d k 4^{\mathrm{R} / \mathrm{R}}$ and $m T E R C^{+/+} C d k 4^{\mathrm{R} / \mathrm{R}}$ mice.

While neoplasms occurred in a number of organs at low incidence, highest tumor incidence occurred in the pituitary and the endocrine pancreas in both groups (Table 3). In addition, hemangiosarcomas were diagnosed in a number of organs with a relatively high incidence. The incidences of endocrine pancreatic $(6 / 32 ; 19 \%)$ and pituitary $(5 / 25 ; 20 \%)$ neoplasms were significantly reduced in $m T E R C^{-/-} C d k 4^{\mathrm{R} / \mathrm{R}}$ mice compared to $m T E R C^{+/+}$ $C d k 4^{\mathrm{R} / \mathrm{R}}$ mice (Table 4). The reduction in occurrence of endocrine pancreas and pituitary neoplasms in $m T E R C^{-/-}$ $C d k 4^{\mathrm{R} / \mathrm{R}}$ mice is further accentuated when sexes are combined to quantify neoplasm incidence (Table 4). The relative frequency of endocrine pancreas tumorigenesis was assessed in both the groups of mice by Kaplan Meier estimation (Figure 5B). These analyses revealed a significant reduction in endocrine pancreatic tumor development in $m T E R C^{-/-} C d k 4^{\mathrm{R} / \mathrm{R}}$ mice (4 of 32 mice; $13 \%$ ) compared to those observed in the $m T E R C^{+/+} C d k 4^{R / R}$ mice (11 of 24 mice; 46\%). Again, according to the logrank test we observed a significant difference between the two groups ( $p=0.0077)$. Similarly, the relative frequency of pituitary tumorigenesis was assessed in both the groups of mice by Kaplan Meier estimation (Figure 5C). During 24 months, 17 of $27 m T E R C^{+/+} C d k 4^{\mathrm{R} / \mathrm{R}}$ mice developed pituitary tumors and only 5 of 32 mice in $m T E R C^{-/-}$ $C d k 4^{\mathrm{R} / \mathrm{R}}$ group developed pituitary tumors. According to the log-rank test, there was significant difference between two groups $(p<0.0001)$.

\section{DISCUSSION}

Intermediary proteins in the RB tumor suppressor pathway, Cdk4 and p16 $6^{\text {Ink4a }}$, govern critical checkpoints that monitor cellular aging, senescence, immortalization capacity and transformation potential [13, 47, 48]. Both $\mathrm{RB} / \mathrm{p} 16$ Ink4a inactivation and telomerase activity are required to immortalize human epithelial cells [27]. However, mutation in the p53 tumor suppressor pathway appears to be obligatory for telomere-dysfunction induced tumor progression [37]. p16 $6^{\text {Ink4a }}$ is encoded by the INK4A locus that also codes for the $\mathrm{p} 19^{\mathrm{ARF}}$ protein which regulates the p53 tumor suppressor pathway. Germline inactivation of the INK4A locus, which abrogates the function of both p16 ${ }^{\text {Ink4a }}$ and p19 ${ }^{\mathrm{ARF}}$ [49], promotes tumorigenesis [50]. In conjunction with telomere dysfunction, inactivation of the INK4A locus results in suppression of cell transformation [38] and reduction of in vivo tumorigenesis [44].Further, it was recently shown that $p 16^{I N K 4 a}$ exerts protective functions in proliferative cells bearing dysfunctional telomeres [51]. Here, using a mouse model that harbors a p16 ${ }^{\text {Ink4a }}$-insensitive $C d k 4^{\mathrm{R} 24 \mathrm{C}}$ mutation in concert with telomere dysfunction, we have examined the effects of $\mathrm{Cdk} 4$ and $\mathrm{p} 16^{\text {Ink4a }}$ activities in telomere dysfunction regulated tumorigenesis. Further, the $C d k 4^{\mathrm{R} 24 \mathrm{C}}$ model is highly susceptible to spontaneous tumors within the pituitary and endocrine pancreas making this model appropriate to study the tumor biology of multiple endocrine organs, a hallmark feature of MEN syndromes.

We demonstrate that cells with the $C d k 4^{\mathrm{R} 24 \mathrm{C}}$ mutation display increased telomerase activity and telomere length. The $C d k 4^{\mathrm{R} 24 \mathrm{C}}$ mutation co-operates with telomere dysfunction to enhance aneuploidy and chromosomal aberrations. However, telomere dysfunction reduces the cell growth rate and transformation potential of $m T E R C^{-/-} C d k 4^{R / R}$ cells. Further, $m T E R C^{-/-} C d k 4^{\mathrm{R} / \mathrm{R}}$ mice exhibit reduced tumor susceptibility primarily due to suppression of tumor initiation and increased latency of tumor development. Furthermore, the islet proliferation capacity in $m T E R C^{-/-} C d k 4^{R / R}$ mice was reduced. Strikingly, pituitary and endocrine pancreas tumorigenesis was significantly suppressed in $m T E R C^{-/} C d k 4^{R / R}$ mice. Taken together, the decreased tumorigenesis and increased survival in $m T E R C^{-/-} C d k 4^{\mathrm{R} / \mathrm{R}}$ mice suggest that the significant telomere shortening and loss of telomere function reduces cancer incidence in mice homozygous for the $C d k 4^{R 24 C}$ allele.

The $C d k 4^{R 24 C}$ mutation promotes cell proliferation and aneuploidy in addition to inducing cytogenetic abnormalities. It is plausible that enhanced proliferation triggers the apoptotic elimination of cells at risk for transformation and thereby reduces tumor initiation in the $m T E R C^{-/-} C d k 4^{R / R}$ mice. Further, telomere dysfunction activates the p53-dependent double-strand break DNA damage pathway [52]. When the p53 checkpoint is subverted by inactivation of the p53 locus, telomere dysfunction promotes rampant genomic instability and aggressive tumorigenesis in late-generation $m T E R C^{-/-} p 53$ mutant mice [37]. In contrast, an intact p53 checkpoint suppresses telomere-dysfunction induced carcinogenesis 
in the Ink4a/Arf mutant mice [38]. Our results of reduced in vivo tumorigenesis in the late generation the $m T E R C^{-/-}$ $C d k 4^{\mathrm{R} / \mathrm{R}}$ mutant mice are consistent with those of Khoo et al that report a decrease in tumor incidence and increases tumor latency in late-generation $\mathrm{mTERC}^{-/-}$Ink4a/Arf mutant mice [44]. We consider it plausible that telomere dysfunction in $m T E R C^{-/-} C d k 4^{R / R}$ mice elicits a p53dependent DNA damage response that reduces tumor initiation.

Recent studies have postulated the importance of p53-mediated senescence as a potential mechanism that precludes in vivo tumorigenesis in cells experiencing telomere dysfunction [52-55]. p16 ${ }^{\text {Ink4a }}$ controls the cellular senescence checkpoint and expression levels of $\mathrm{p} 16^{\text {Ink4a }}$ increase in an age-dependent manner [15]. However, our study as well as the one published by Khoo et al., [44] are consistent with different pathways governing, (i) cellular senescence, and, (ii) telomere-dysfunction induced senescence. It is plausible that the $\mathrm{RB} / \mathrm{p} 16^{\text {Ink4a }}$ pathway, whereas required for cellular senescence and aging, may be dispensable for telomere dysfunction induced senescence. Instead, the p53 pathway may serve as the primary checkpoint that promotes telomere-dysfunction induced senescence and precludes tumor development in the setting of telomere dysfunction. As an extension, we speculate that tumors arising in the $m T E R C^{-/-} C d k 4^{\mathrm{R} / \mathrm{R}}$ mice may have incurred p53 pathway mutations that abrogate p53-mediated telomere induced senescence. Alternatively, tumors that develop in the $m T E R C^{-/-} C d k 4^{\mathrm{R} / \mathrm{R}}$ mice may have activated alternate (ALT) pathways of telomere elongation and maintenance to promote tumorigenesis [56]. It was recently shown that reactivation of telomerase in the setting of telomere dysfunction in a prostate cancer-prone Pten and p53 null mouse enables malignant progression [57].

Telomerase activation is known to be a common event in human cancer and considered to be a useful marker for malignancy [46]. We show that telomere dysfunction effectively suppresses endocrine tumor initiation and increases tumor latency. These results, taken together, support the application of anti-telomerase inhibitor approaches to specific human cancers that harbor RB pathway mutations. However, we rationalize that the anti-telomerase inhibitor approach should be restrictive to tumors that harbor an intact p53 checkpoint. Telomerase activity is elevated in late stage islet tumors in the rat-insulin promoter driven SV40 T antigen mouse model of islet carcinogenesis [58]. We show here that $C d k 4^{\mathrm{R} 24 \mathrm{C}}$ induced islet carcinogenesis involves increased telomerase activity. Telomere dysfunction significantly reduces endocrine pancreas and pituitary tumors in the $C d k 4^{\mathrm{R} 24 \mathrm{C}}$ mice which is consistent with an important role for telomerase in endocrine tumorigenesis. The MEN1 mouse models reproducibly elicit the MEN1 syndrome with regards to increased susceptibility of tumors within the endocrine pancreas, pituitary and parathyroid organs
[6-9]. However, the role of telomerase activation and telomere length regulation within the context of MEN1 mutations is unknown. Moreover, although telomerase activity is increased in many human malignancies, the role for telomerase activity in the human MEN syndrome, and specifically in MEN1, is obscure. Our results are strongly suggestive of elevated telomerase activity and deregulated telomere length in human MEN tumors and, thereby, advocate the utility of anti-telomerase inhibitors to treat multiple endocrine malignancies.

\section{EXPERIMENTAL METHODS}

\section{Telomerase activity}

Islets were isolated from 17-month-old $C d k 4^{+/+}$ and $C d k 4^{\mathrm{R} / \mathrm{R}}$ mice by collagenase digestion (Liberase, Roche Diagnostics, IN) followed by centrifugation over a Histopaque gradient (Sigma, St. Louis, MO). Islets were handpicked under a stereo microscope and were used for protein analysis. MEFs from $C d k 4^{+/+}$and $C d k 4^{\mathrm{R} / \mathrm{R}}$ mice were isolated from individual embryos at 13.5 days as previously described [19, 23]. Telomerase activity was determined using TRAPeze telomerase detection kit (Intergene, NY). The same amount of protein (500ng/ assay) was used for the telomerase activity detection.

\section{Generation of $m T E R C^{-/-} C d k 4^{\mathrm{R} / \mathrm{R}}$ mice}

$C d k 4^{R / R}$ mice were bred with $m T E R C^{-/}$mice to generate heterozygous $m T E R C^{+/-} C d k 4^{+/ R 24 C}$ mice. These mice were inter-crossed to obtain successive generations of G2, G3, G4, G5 and G6 mTERC $C^{-/-} C d k 4^{\mathrm{R} / \mathrm{R}}$ and $m T E R C^{+/+} C d k 4^{\mathrm{R} / \mathrm{R}}$ mice. All experiments described in this study involved the use of G5 or G6 generation of mice. All animals were maintained under a 12 hour day/12 hour night cycle. All animal experiments were conducted under guidelines and protocols approved by the Animal Care and Use Committee and animal care was provided in accordance with the procedures outlined in the Guide for Care and Use of Laboratory Animals (National Research Council; 2011; National Academy Press; Washington, D.C.).

\section{Growth curve analysis and colony formation assays}

For growth curve estimation, $5 \times 10^{4} \mathrm{MEF}$ cells from G5 mice were plated on 6-well plates and media was changed every three days. To test for the ability of cells to form colonies when plated at low density, MEF cells were seeded in triplicate at 3500 cells per 6-well plates and cultured in media containing 10\% FBS. After 2 weeks 
of culture, cells were washed with PBS, fixed in methanol, stained with Giemsa stain and the number of colonies was counted.

\section{Quantitative telomeric FISH and spectral karyotyping}

Telomere length and spectral karyotyping determinations were performed on MEF cultures as described previously [43]. Metaphase chromosomes and FISH of telomeric sequences were performed with Cy3 labeled TTAGGG peptide nucleic acid probe. Spectral karyotyping of MEFs was done according to the manufacturer protocol. At least 12 metaphases were analyzed for each sample.

\section{Tumor incidence and histopathology analyses}

Mice were observed for 24 months for appearance of detectable or palpable tumors. Mice were examined closely for evidence of ill health or overt tumor growth during weekly inspections of the mouse colony. Tumorbearing mice were euthanized and comprehensive necropsies were performed. Tissues were fixed in 10\% buffered neutral formalin, paraffin-embedded, sectioned at 5 microns and stained with hematoxylin and eosin. At the end of 24 months, the remaining mice were euthanized and grouped into tumor-prone or tumor free categories. Mice were euthanized if profoundly ill or if external tumors exceeded $2 \mathrm{~cm}$ in diameter and scored as a death in Kaplan-Meier survive analysis. Only those animals with a histologically proven cancer, as determined by a veterinary pathologist in the group (Dr. Miriam Anver), were scored as a tumor incidence event in the tumor analysis.

\section{Immunohistochemistry}

Immunohistochemistry was performed by routine methods as described previously [59]. Normal and tumor tissues were fixed by immersion in either $10 \%$ neutral buffered formalin or 95\% EtOH/5\% glacial acetic acid overnight, dehydrated through ethanol and embedded in paraffin. Blocks were sectioned at $5 \mu \mathrm{m}$ and stained with hematoxylin and eosin or prepared for immunohistochemistry by mounting tissue sections on electrostatically charged slides (ProbeOn Plus, Fisher Scientific). Antibody sources are, insulin (guinea pig antiinsulin polyclonal antibody, DAKO Inc., Indiana) and $\beta$-catenin (BD Transduction Laboratories, Cat No. 610153, Mouse IgG1). Analysis of immunohistochemistry was done to determine the distinct localization pattern (nuclear, cytoplasmic and nucleocytoplasmic).

\section{Telomere length and Ki-67 staining}

Telomere length was analyzed in pancreatic islets from 4 telomerase positive and 5 negative mice by using iCys (CompuCyte, MA) image cytometry as described previously [43]. In each sample 8-22 islets were scored. Islets were defined by insulin staining, with exception of sample plus $2 \mathrm{a}$, which scores represented different regions from 2 big tumors that were not having insulin staining. In each islet, a ratio between telomere and centromere signal in phantom areas, which size was approximately equal to the size of cells was measured and the mean values is shown in the box chart plot. And the same sample sections as before for telomere length analysis were stained with Ki-67, insulin antibodies, and DAPI. The pancreatic islets on these sections were contoured. Within each contour, the total number of $8 \mu \mathrm{m}$ diameter circle-phantoms containing DAPI staining was calculated, which approximately corresponded to cell number $(\mathrm{C})$. Then we estimated the number of the phantoms, which had Ki-67 staining $(\mathrm{K})$. The part of stained cells was calculated as $\mathrm{P}=\mathrm{K} / \mathrm{C}$ and plotted on Y-axis for each islet.

\section{ACKNOWLEDGEMENTS}

The authors thank Stephen Marx and Sunita Agarwal (NIDDK) for critical reading of the manuscript. This work was supported by funds from the NIH intramural program. This project has been funded in part with federal funds from the National Cancer Institute, National Institutes of Health, under Contract No. HHSN261200800001E. The content of this publication does not necessarily reflect the views of policies of the Department of Health and Human Services, nor does mention of trade names, commercial products, or organizations imply endorsement by the U.S. Government.

\section{REFERENCES}

1. Marx SJ. Molecular genetics of multiple endocrine neoplasia types 1 and 2. Nature reviews. 2005; 5(5):367375 .

2. Spiegel AM. Focus on hereditary endocrine neoplasia. Cancer Cell. 2004; 6(4):327-332.

3. Agarwal SK, Kester MB, Debelenko LV, Heppner C, Emmert-Buck MR, Skarulis MC, Doppman JL, Kim YS, Lubensky IA, Zhuang Z, Green JS, Guru SC, Manickam P, Olufemi SE, Liotta LA, Chandrasekharappa SC, et al. Germline mutations of the MEN1 gene in familial multiple endocrine neoplasia type 1 and related states. Hum Mol Genet. 1997; 6(7):1169-1175.

4. Chandrasekharappa SC, Guru SC, Manickam P, Olufemi SE, Collins FS, Emmert-Buck MR, Debelenko LV, Zhuang Z, Lubensky IA, Liotta LA, Crabtree JS, Wang Y, Roe BA, Weisemann J, Boguski MS, Agarwal SK, et al. Positional 
cloning of the gene for multiple endocrine neoplasia-type 1 . Science. 1997; 276(5311):404-407.

5. Lemmens I, Van de Ven WJ, Kas K, Zhang CX, Giraud S, Wautot V, Buisson N, De Witte K, Salandre J, Lenoir G, Pugeat M, Calender A, Parente F, Quincey D, Gaudray P, De Wit MJ, et al. Identification of the multiple endocrine neoplasia type 1 (MEN1) gene. The European Consortium on MEN1. Hum Mol Genet. 1997; 6(7):1177-1183.

6. Crabtree JS, Scacheri PC, Ward JM, Garrett-Beal L, Emmert-Buck MR, Edgemon KA, Lorang D, Libutti SK, Chandrasekharappa SC, Marx SJ, Spiegel AM and Collins FS. A mouse model of multiple endocrine neoplasia, type 1, develops multiple endocrine tumors. Proc Natl Acad Sci U S A. 2001; 98(3):1118-1123.

7. Bertolino P, Tong WM, Herrera PL, Casse H, Zhang CX and Wang ZQ. Pancreatic beta-cell-specific ablation of the multiple endocrine neoplasia type 1 (MEN1) gene causes full penetrance of insulinoma development in mice. Cancer Res. 2003; 63(16):4836-4841.

8. Biondi CA, Gartside MG, Waring P, Loffler KA, Stark MS, Magnuson MA, Kay GF and Hayward NK. Conditional inactivation of the MEN1 gene leads to pancreatic and pituitary tumorigenesis but does not affect normal development of these tissues. Mol Cell Biol. 2004; 24(8):3125-3131.

9. Crabtree JS, Scacheri PC, Ward JM, McNally SR, Swain GP, Montagna C, Hager JH, Hanahan D, Edlund H, Magnuson MA, Garrett-Beal L, Burns AL, Ried T, Chandrasekharappa SC, Marx SJ, Spiegel AM, et al. Of mice and MEN1: Insulinomas in a conditional mouse knockout. Mol Cell Biol. 2003; 23(17):6075-6085.

10. Jacks T, Fazeli A, Schmitt EM, Bronson RT, Goodell MA and Weinberg RA. Effects of an Rb mutation in the mouse. Nature. 1992; 359(6393):295-300.

11. Loffler KA, Biondi CA, Gartside MG, Serewko-Auret MM, Duncan R, Tonks ID, Mould AW, Waring P, Muller HK, Kay GF and Hayward NK. Lack of augmentation of tumor spectrum or severity in dual heterozygous Men1 and Rb1 knockout mice. Oncogene. 2007; 26(27):4009-4017.

12. Chau BN and Wang JY. Coordinated regulation of life and death by RB. Nature reviews. 2003; 3(2):130-138.

13. Malumbres $\mathrm{M}$ and Barbacid $\mathrm{M}$. Mammalian cyclindependent kinases. Trends Biochem Sci. 2005; 30(11):630641.

14. Malumbres M and Barbacid M. Cell cycle kinases in cancer. Curr Opin Genet Dev. 2007; 17(1):60-65.

15. Collado M, Blasco MA and Serrano M. Cellular senescence in cancer and aging. Cell. 2007; 130(2):223-233.

16. Sharpless NE and DePinho RA. How stem cells age and why this makes us grow old. Nat Rev Mol Cell Biol. 2007; 8(9):703-713.

17. Gil J and Peters G. Regulation of the INK4b-ARF-INK4a tumour suppressor locus: all for one or one for all. Nat Rev Mol Cell Biol. 2006; 7(9):667-677.
18. Kim SY and Rane SG. The Cdk4-E2f1 pathway regulates early pancreas development by targeting Pdx1+ progenitors and Ngn3+ endocrine precursors. Development (Cambridge, England). 2011; 138(10):1903-1912.

19. Rane SG, Dubus P, Mettus RV, Galbreath EJ, Boden G, Reddy EP and Barbacid M. Loss of Cdk4 expression causes insulin-deficient diabetes and $\mathrm{Cdk} 4$ activation results in beta-islet cell hyperplasia. Nature genetics. 1999; 22(1):4452.

20. Lee JH, Jo J, Hardikar AA, Periwal V and Rane SG. Cdk4 regulates recruitment of quiescent beta-cells and ductal epithelial progenitors to reconstitute beta-cell mass. PloS one. 2010; 5(1):e8653.

21. Jirawatnotai S, Aziyu A, Osmundson EC, Moons DS, Zou $\mathrm{X}$, Kineman RD and Kiyokawa H. Cdk4 is indispensable for postnatal proliferation of the anterior pituitary. J Biol Chem. 2004; 279(49):51100-51106.

22. Moons DS, Jirawatnotai S, Parlow AF, Gibori G, Kineman RD and Kiyokawa H. Pituitary hypoplasia and lactotroph dysfunction in mice deficient for cyclin-dependent kinase-4. Endocrinology. 2002; 143(8):3001-3008.

23. Rane SG, Cosenza SC, Mettus RV and Reddy EP. Germ line transmission of the Cdk4(R24C) mutation facilitates tumorigenesis and escape from cellular senescence. Molecular and cellular biology. 2002; 22(2):644-656.

24. Sotillo R, Dubus P, Martin J, de la Cueva E, Ortega S, Malumbres $\mathrm{M}$ and Barbacid $\mathrm{M}$. Wide spectrum of tumors in knock-in mice carrying a Cdk4 protein insensitive to INK4 inhibitors. Embo J. 2001; 20(23):6637-6647.

25. Gillam MP, Nimbalkar D, Sun L, Christov K, Ray D, Kaldis $\mathrm{P}$, Liu X and Kiyokawa H. MEN1 tumorigenesis in the pituitary and pancreatic islet requires $\mathrm{Cdk} 4$ but not $\mathrm{Cdk} 2$. Oncogene. 2014.

26. Krishnamurthy J, Ramsey MR, Ligon KL, Torrice C, Koh A, Bonner-Weir S and Sharpless NE. p16INK4a induces an age-dependent decline in islet regenerative potential. Nature. 2006; 443(7110):453-457.

27. Kiyono T, Foster SA, Koop JI, McDougall JK, Galloway DA and Klingelhutz AJ. Both Rb/p16INK4a inactivation and telomerase activity are required to immortalize human epithelial cells. Nature. 1998; 396(6706):84-88.

28. Garcia-Cao M, Gonzalo S, Dean D and Blasco MA. A role for the $\mathrm{Rb}$ family of proteins in controlling telomere length. Nat Genet. 2002; 32(3):415-419.

29. Greider $\mathrm{CW}$ and Blackburn EH. Identification of a specific telomere terminal transferase activity in Tetrahymena extracts. Cell. 1985; 43(2 Pt 1):405-413.

30. Blackburn EH, Greider CW and Szostak JW. Telomeres and telomerase: the path from maize, Tetrahymena and yeast to human cancer and aging. Nat Med. 2006; 12(10):11331138.

31. Blasco MA, Lee HW, Hande MP, Samper E, Lansdorp PM, DePinho RA and Greider CW. Telomere shortening and tumor formation by mouse cells lacking telomerase RNA. 
Cell. 1997; 91(1):25-34.

32. Lee HW, Blasco MA, Gottlieb GJ, Horner JW, 2nd, Greider $\mathrm{CW}$ and DePinho RA. Essential role of mouse telomerase in highly proliferative organs. Nature. 1998; 392(6676):569574.

33. Chiang YJ, Hemann MT, Hathcock KS, Tessarollo L, Feigenbaum L, Hahn WC and Hodes RJ. Expression of telomerase RNA template, but not telomerase reverse transcriptase, is limiting for telomere length maintenance in vivo. Mol Cell Biol. 2004; 24(16):7024-7031.

34. Liu Y, Snow BE, Hande MP, Yeung D, Erdmann NJ, Wakeham A, Itie A, Siderovski DP, Lansdorp PM, Robinson MO and Harrington L. The telomerase reverse transcriptase is limiting and necessary for telomerase function in vivo. Curr Biol. 2000; 10(22):1459-1462.

35. Yuan X, Ishibashi S, Hatakeyama S, Saito M, Nakayama J, Nikaido R, Haruyama T, Watanabe Y, Iwata H, Iida M, Sugimura H, Yamada N and Ishikawa F. Presence of telomeric G-strand tails in the telomerase catalytic subunit TERT knockout mice. Genes to cells : devoted to molecular \& cellular mechanisms. 1999; 4(10):563-572.

36. Artandi SE, Chang S, Lee SL, Alson S, Gottlieb GJ, Chin $\mathrm{L}$ and DePinho RA. Telomere dysfunction promotes nonreciprocal translocations and epithelial cancers in mice. Nature. 2000; 406(6796):641-645.

37. Chin L, Artandi SE, Shen Q, Tam A, Lee SL, Gottlieb GJ, Greider CW and DePinho RA. p53 deficiency rescues the adverse effects of telomere loss and cooperates with telomere dysfunction to accelerate carcinogenesis. Cell. 1999; 97(4):527-538.

38. Greenberg RA, Chin L, Femino A, Lee KH, Gottlieb GJ, Singer RH, Greider CW and DePinho RA. Short dysfunctional telomeres impair tumorigenesis in the INK4a(delta2/3) cancer-prone mouse. Cell. 1999; 97(4):515-525.

39. Rudolph KL, Millard M, Bosenberg MW and DePinho RA. Telomere dysfunction and evolution of intestinal carcinoma in mice and humans. Nat Genet. 2001; 28(2):155-159.

40. Wong KK, Maser RS, Bachoo RM, Menon J, Carrasco DR, Gu Y, Alt FW and DePinho RA. Telomere dysfunction and Atm deficiency compromises organ homeostasis and accelerates ageing. Nature. 2003; 421(6923):643-648.

41. Harley CB. Telomerase and cancer therapeutics. Nature reviews. 2008; 8(3):167-179.

42. Shay JW and Wright WE. Telomerase therapeutics for cancer: challenges and new directions. Nat Rev Drug Discov. 2006; 5(7):577-584.

43. Hu J, Hwang SS, Liesa M, Gan B, Sahin E, Jaskelioff M, Ding Z, Ying H, Boutin AT, Zhang H, Johnson S, Ivanova E, Kost-Alimova M, Protopopov A, Wang YA, Shirihai OS, et al. Antitelomerase therapy provokes ALT and mitochondrial adaptive mechanisms in cancer. Cell. 2012; 148(4):651-663.

44. Khoo CM, Carrasco DR, Bosenberg MW, Paik JH and
Depinho RA. Ink4a/Arf tumor suppressor does not modulate the degenerative conditions or tumor spectrum of the telomerase-deficient mouse. Proc Natl Acad Sci U S A. 2007; 104(10):3931-3936.

45. Semba S, Kusumi R, Moriya T and Sasano H. Nuclear Accumulation of B-Catenin in Human Endocrine Tumors: Association with Ki-67 (MIB-1) Proliferative Activity. Endocr Pathol. 2000; 11(3):243-250.

46. Stewart SA and Weinberg RA. Telomeres: cancer to human aging. Annual review of cell and developmental biology. 2006; 22:531-557.

47. Malumbres $\mathrm{M}$ and Barbacid $\mathrm{M}$. To cycle or not to cycle: a critical decision in cancer. Nature reviews. 2001; 1(3):222231.

48. Ortega S, Malumbres $\mathrm{M}$ and Barbacid $\mathrm{M}$. Cyclin D-dependent kinases, INK4 inhibitors and cancer. Biochim Biophys Acta. 2002; 1602(1):73-87.

49. Haber DA. Splicing into senescence: the curious case of $\mathrm{p} 16$ and p19ARF. Cell. 1997; 91(5):555-558.

50. Serrano M, Lee H, Chin L, Cordon-Cardo C, Beach D and DePinho RA. Role of the INK4a locus in tumor suppression and cell mortality. Cell. 1996; 85(1):27-37.

51. Wang Y, Sharpless N and Chang S. p16(INK4a) protects against dysfunctional telomere-induced ATR-dependent DNA damage responses. J Clin Invest. 2013; 123(10):44894501.

52. Deng Y, Chan SS and Chang S. Telomere dysfunction and tumour suppression: the senescence connection. Nature reviews. 2008; 8(6):450-458.

53. Cosme-Blanco W, Shen MF, Lazar AJ, Pathak S, Lozano G, Multani AS and Chang S. Telomere dysfunction suppresses spontaneous tumorigenesis in vivo by initiating p53-dependent cellular senescence. EMBO reports. 2007; 8(5):497-503.

54. Feldser DM and Greider CW. Short telomeres limit tumor progression in vivo by inducing senescence. Cancer cell. 2007; 11(5):461-469.

55. Sedivy JM. Telomeres limit cancer growth by inducing senescence: long-sought in vivo evidence obtained. Cancer Cell. 2007; 11(5):389-391.

56. Reddel RR. Alternative lengthening of telomeres, telomerase, and cancer. Cancer Lett. 2003; 194(2):155-162.

57. Ding Z, Wu CJ, Jaskelioff $\mathrm{M}$, Ivanova $\mathrm{E}$, Kost-Alimova M, Protopopov A, Chu GC, Wang G, Lu X, Labrot ES, Hu J, Wang W, Xiao Y, Zhang H, Zhang J, Gan B, et al. Telomerase reactivation following telomere dysfunction yields murine prostate tumors with bone metastases. Cell. 2012; 148(5):896-907.

58. Blasco MA, Rizen M, Greider CW and Hanahan D. Differential regulation of telomerase activity and telomerase RNA during multi-stage tumorigenesis. Nat Genet. 1996; 12(2):200-204.

59. Jiao W, Lin HM, Datta J, Braunschweig T, Chung JY, Hewitt SM and Rane SG. Aberrant nucleocytoplasmic 
localization of the retinoblastoma tumor suppressor protein in human cancer correlates with moderate/poor tumor differentiation. Oncogene. 2008; 27(22):3156-3164. 